\title{
Hepatocytes express the antimicrobial peptide HBD-2 after multiple trauma: an experimental study in human and mice
}

Stefanie Fitschen-Oestern ${ }^{1 \dagger}$, Matthias Weuster ${ }^{1 \dagger}$, Sebastian Lippross ${ }^{1}$, Peter Behrendt ${ }^{1}$, Sabine Fuchs ${ }^{1}$, Thomas Pufe ${ }^{2}$, Mersedeh Tohidnezhad ${ }^{2}$, Andreas Bayer ${ }^{3}$, Andreas Seekamp $^{1}$, Deike Varoga ${ }^{1}$ and Tim Klüter ${ }^{1 *}$

\begin{abstract}
Background: Human-beta defensins (HBD) belong to the family of acute phase peptides and hold a broad antimicrobial spectrum that includes gram-positive and gram-negative bacteria. HBD are up-regulated after severe injuries but the source of posttraumatic HBD expression has not been focused on before.

In the current study we analysed the role of liver tissue in expression of HBD after multiple trauma in human and mice.
\end{abstract}

Methods: HBD-2 expression has been detected in plasma samples of 32 multiple trauma patients (ISS > 16) over 14 days after trauma by ELISA. To investigate major sources of HBD-2, its expression and regulation in plasma samples, polymorphonuclear neutrophils (PMN) and human tissue samples of liver and skin were analysed by ELISA. As liver samples of trauma patients are hard to obtain we tried to review findings in an established trauma model. Plasma samples and liver samples of 56 male C57BL/6 N-mice with a thorax trauma and a femur fracture were analysed by ELISA, real-time PCR and immunohistochemistry for murine beta defensin 4 (MBD-4) and compared with the expression of control group without trauma.

The induction of HBD-2 expression in cultured hepatocytes (Hep G2) was analysed after incubation with IL-6, supernatant of Staphylococcus aureus (SA) and Lipopolysaccharides (LPS). One possible signalling pathway was tested by blocking toll-like receptor 2 (TLR2) in hepatocytes.

Results: Compared to healthy control group, plasma of multiple traumatized patients and mice showed significantly higher defensin levels after trauma. Compared to skin cells, which are known for high beta defensin expression, liver tissue showed less HBD-2 expression, but higher HBD-2 expression compared to PMN. Immunhistochemical staining demonstrated upregulated MBD-4 in hepatocytes of traumatised mice. In HepG2 cells HBD-2 expression could be increased by stimulation with IL-6 and SA. Neutralization of HepG2 cells with aTLR2 showed reduced HBD-2 expression after stimulation with SA.

Conclusion: Plasma samples of multiple traumatized patients showed high expression of HBD-2, which may protect the severely injured patient from overwhelming bacterial infection. Our data support the hypothesis that liver is one possible source for HBD-2 in plasma while posttraumatic inflammatory response.

Keywords: Antimicrobial peptides, Multiple trauma, Human beta-defensin, Liver, Hepatocytes, MBD

\footnotetext{
* Correspondence: Tim.Klueter@uksh.de

${ }^{\dagger}$ Equal contributors

${ }^{1}$ Department of Trauma Surgery, University Medical Center of

Schleswig-Holstein, Campus Kiel, Arnold-Heller-Strasse 3, 24105 Kiel, Germany

Full list of author information is available at the end of the article
} 


\section{Background}

Multiple trauma is still the most frequent cause of death in people under 40 years. Due to direct exposure of soft tissue and bone to bacteria in case of open fracture and soft tissue damage multiple traumatized patients are highly susceptible to infectious complications [1, 2]. Furthermore severe injuries lead to a depression of the immune system [3] which favours infectious complications [4].

In previous studies we could demonstrate, that hostdefence peptides (HDP) are induced in plasma of multiple injured patients and provide extended antimicrobial capacity [5].

Such peptides constitute an innate defence mechanism that has been shown to be present in various kinds of tissue like skin, lung, brain, stomach and bladder [6-8]. HBDs generally display potent activity against grampositive as well as gram-negative bacteria, virus and fungi [9]. Additionally defensins and cathelicidins activate $\mathrm{T}$ - and B-cells, support wound healing and angiogenesis and induce the attraction of neutrophils [10-13]. So far the sources of HDP in plasma of trauma patients have not been identified yet. In contrast to that many sources of inflammatory mediators and cytokines that contribute to the posttraumatic inflammatory reaction have been described several times [14]. Liver tissue has been attributed with a special role in the release of such mediators $[15,16]$. Large amounts of IL-6 are locally produced in the liver by Kupffer cells. Following major trauma the IL-6 release correlates with injury severity and mortality [17]. IL-6 is also known as a main inducer of HBD-2 in vitro and can potentiate the microbial killing activity of HBD-2 [18].

With regard to the potential of HDP in treatment of multiple injured patients it is indispensable to discover HDP producing cells and determine possible pathways for its regulation.

The aim of this study was to detect possible sources for HDP in plasma of multiple injured patients and to find inducers and mechanisms of induction. As liver constitutes an organ, which is vulnerable to trauma damage and additionally plays a major role in the posttraumatic inflammatory response, we focus on liver tissue and compared this to skin as a well know producer of HBD-2. Due to the fact that human liver tissue of multiple injured patients is hardly available for research, we investigated the regulation of murine beta defensin 4 (MBD-4) [19], which is comparable to the human HBD-2, in liver of an established multiple trauma mouse model.

\section{Methods}

\section{Patient population}

Thirty two adult patients with multiple injuries (aged 18-65 years, male and female) were studied at the
Department of Trauma Surgery of the University Medical Center of Schleswig-Holstein, Campus Kiel and the Hannover Medical School, Germany. Data were analysed retrospectively. Inclusion criteria were an injury severity score (ISS) of greater than 16 points without the presence of severe traumatic brain injury (though abbreviated injury scales for head injury were included in the ISS) and primary admission to the institutions. Exclusion criteria were penetrating trauma and no direct admission to either institution following the traumatic event. All procedures were in concordance with the Revised Version of the Declaration of Helsinki. The Ethics committee approval was obtained prior to the study for trauma patient as well as for volunteer (control group) sample analysis (AZ: D 415/08).

\section{Control group}

A group of 6 volunteers ( 3 women and 3 men), age 20 to 40 years, was randomly selected for determination of the normal baseline values. Inclusion criteria were no previous diseases, no medication or trauma and no previous operations.

\section{Collection of blood}

Venous EDTA-blood ( $9 \mathrm{ml}$ Monovette, Sarstedt, Germany) was collected daily at 7 a.m. from traumatized patients over a 14-day period. The first sample was drawn directly after admission to the hospital. Within $30 \mathrm{~min}$ the blood was centrifuged for $10 \mathrm{~min}$ at $2000 \mathrm{~g}$ at room temperature. The supernatant plasma was stored at $-80{ }^{\circ} \mathrm{C}$.

\section{Recruitment of tissues}

Epidermis was collected from 5 patients undergoing osteosynthesis after fracture. After skin incision a $50 \times$ $2 \mathrm{~mm}$ piece of epidermis was cut for further examinations. Liver tissue was harvested from 5 patients undergoing liver resection. $10 \mathrm{mg}$ of macroscopic healthy tissue was cut for further examination. All operations were performed at the Departments for Trauma Surgery and Visceral Surgery at the University Medical Centre of Schleswig-Holstein, Kiel Campus. The local ethics committee approval was obtained for the study (AZ: D412/08).

\section{Isolation of PMN with polymorph-prep $\odot$}

Venous blood samples of $9 \mathrm{~mL}$ were taken from 5 healthy volunteers by the use of EDTA Monovettes. PMN were isolated from whole blood using PolymorphPrep@ (Axis-Shield, Norway) according to the manufacturer's instructions. $5 \mathrm{~mL}$ of blood was carefully layered on $5 \mathrm{~mL}$ of Polymorph-Prep@). After centrifuging at $500 \times \mathrm{g}$ for $30 \mathrm{~min}$ at room temperature mononuclear cells and polymorphonuclear cells were separated and resuspended in $0.45 \% \mathrm{NaCl}$. 


\section{Cultivation and stimulation of immortalized liver cells}

The experiments were performed with immortalized liver cells, HepG2 (Cell Lines Service, Germany). These cells represent histological and biological characteristics of differentiated parenchymal liver cells [20].

Cells were cultivated as described in distributer's instructions. For cultivation 800,000 cells were filled into a $25 \mathrm{~cm}^{2}$ cell culture bottle with $2 \mathrm{~mL}$ of cell medium. Cells were stimulated with $50 \mathrm{ng} / \mathrm{mL}$ IL-6 (Tebu, Offenbach, Germany) and supernatant of SA (1:100, assembled as described by Gläser et al. [21]).

For neutralisation experiments, 400,000 cells were cultivated, incubated with $10 \mu \mathrm{g} / \mathrm{mL}$ TLR2 antibody (eBioscience, San Diego, USA) for $1 \mathrm{~h}$ and stimulated afterwards with SA (1:100). Incubation was performed at $37{ }^{\circ} \mathrm{C}$ in ambient humidity with $5 \% \mathrm{CO}_{2}$ in an incubator. All experiments were accomplished three times.

\section{HBD-2 ELISA}

Ninety six-well immunoplates (MaxiSorp, Nunc, Roskilde, Denmark) were coated at $4{ }^{\circ} \mathrm{C}$ for $24 \mathrm{~h}$ with $100 \mu \mathrm{l}$ of capture antibody. The antibodies were diluted in $0.05 \mathrm{M}$ carbonate buffer, $\mathrm{pH}$ 9.6. Afterwards the wells were blocked with $200 \mu \mathrm{l}$ of $1 \%$ bovine serum albumin in PBS for $60 \mathrm{~min}$ at room temperature. After three times washing with $250 \mu \mathrm{l}$ of PBS $+0.05 \%$ Tween 20, $100 \mu \mathrm{l}$ per well of sample was incubated for $60 \mathrm{~min}$ at room temperature. Plates were washed three times with PBS + $0.05 \%$ Tween 20 and wells were incubated for $30 \mathrm{~min}$ at room temperature with $100 \mu \mathrm{l}$ of biotinylated antibody diluted in $10 \mathrm{ml} 0.1 \%$ BSA + PBS. Plates were again washed three times with $\mathrm{PBS}+0.1 \%$ Tween 20 and filled with $100 \mu \mathrm{l} /$ well of StreptavidinHRP (R\&D Systems, Minneapolis, USA) diluted $1: 200$ in PBS $+0.05 \%$ Tween 20. The plates were incubated for $30 \mathrm{~min}$ at room temperature, washed three times as described above and incubated with $100 \mu \mathrm{l} \quad 3.3^{\prime}, 5.5^{\prime}$-Tetramethylbenzidine (Sigma-Aldrich, St. Louis, USA) as the development agent for 5-10 min at room temperature in the dark. Absorbance was measured at $450 \mathrm{~nm}$ with a multichannel photometer (Sunrise; Tecan, Crailsheim, Germany). For the ELISA experiments three wells of each sample were analysed.

For HDB-2 ELISA goat anti-HBD-2 antibody (Acris, Hiddenhausen, Germany; PP1125P2) and biotinylated goat anti-HBD-2 antibody (Acris, Hiddenhausen, Germany; PP1125B2) were used in the concentration 0.5 and $0.25 \mu \mathrm{g} / \mathrm{ml}$. Human recombinant HBD-2 was (Acris, Hiddenhausen, Germany) served as the standard with the following concentrations: $0,0.05,0.1,0.2$, $0.39,0.78,1.56,3.13,6.25 \mathrm{ng} / \mathrm{ml}$. Experiment were accomplished three times.

\section{Immunohistochemistry}

After fixation of human liver samples in 4\% paraformaldehyde, the tissue was embedded in paraffin, sectioned and dewaxed. Endogenous peroxidases in tissue sections were blocked with $3 \% \mathrm{H}_{2} \mathrm{O}_{2}$, and tissue sections were subsequently incubated with normal serum (1:5 in Tris buffered saline (TBS)) from the species in which the primary antibody was raised. Immunohistochemical staining was performed on $6 \mu \mathrm{m}$ paraffin sections, using polyclonal primary antibody against HBD-2 (Goat anti Human Defensin beta 2, diluted 1:200, Acris). Incubation with primary antibody was performed at $4{ }^{\circ} \mathrm{C}$ for $12 \mathrm{~h}$. Incubation with second antibody against HBD-2 (Polyclonal Antibody to Goat IgG, diluted 1:300, Acris) was performed for $45 \mathrm{~min}$ and incubation with streptavidin-peroxidase for $30 \mathrm{~min}$. Afterwards washing for $5 \mathrm{~min}$ was conducted three times. Samples were incubated with DAB (6 mg of 3,3'-Diaminobenzidine tetrahydrochloride in $10 \mathrm{ml}$ distilled water with 2 drops of $3 \% \mathrm{H}_{2} \mathrm{O}_{2}$ ) as chromogen. After washing three times with TBS for 5 min cell nuclei were counterstained with Mayers-Haemalaun for $15 \mathrm{~s}$ followed by rinsing of samples for $5 \mathrm{~min}$ in distilled water. Samples were dehydrated with different concentrations of alcohol (50, 75, 90 and 95\%) and after 5 min covered in Xylol with DPX. Negative control was carried out while dispensing with primary antibody.

\section{Animal care}

Ethical approval has obtained from Ethics Committee of the MHH (Medizinische Hochschule Hannover) (AZ: V 312-72241.121-9 (25-2/11)). The study was performed at the experimental trauma surgery laboratory of the $\mathrm{MHH}$. Experiments were conducted in an operating room at the animal research facility. 56 male C57BL/ $6 \mathrm{~N}$-mice (Charles River, Germany) weighing $22 \pm 3$ g were used for the study. 20 mice were used in preliminary experiments to determine the weight needed for induction of chest trauma.

All mice were handled at room temperature for 14 days before treatment and all mice were at the same age of 12 weeks. Throughout the study period, pelleted mouse chow and water were available ad libitum. The lighting was maintained on a 12-h light-dark cycle. Analgesic treatment was administered to all animals $(200 \mathrm{mg} / \mathrm{kg}$ metamizole sodium (Novalgin ${ }^{\circ}$, Hoechst, Unterschleißheim, Germany)) throughout the study. All surgical procedures were performed under deep anesthesia with isoflurane (Baxter AG, Volketswil, Germany) and local application of xylazine $(16 \mathrm{mg} / \mathrm{kg})$ (Rompun ${ }^{\circ}$, Bayer, Leverkusen, Germany). The mice were warmed to $36{ }^{\circ} \mathrm{C}$ using infrared heat lamps after the surgical procedures were complete. Wound closure was performed before recovery from the anaesthesia. 


\section{Group distribution and experimental procedures}

Two different groups $(n=8)$ were included in the experimental design: a) mice with a femur fracture and chest trauma and b) mice with an intramedullary pin but without chest trauma or femur fracture (control group). The experimental design of the multiple trauma model is based on a two-hit model. The first hit consisted of a closed femur fracture on the right side with the femur stabilized with a cannula before the fracture was performed. The method used for the femur fracture model was first described by Bonnarens (35). After primary wound closure, standardized femur fracture was induced using a blunt guillotine device weighing $500 \mathrm{~g}$ (0.784 J). This resulted in a femoral fracture combined with soft tissue injury. Chest trauma immediately followed femur fracture as the second hit. The chest trauma model was previously described for rats $(36 ; 37)$. Trauma was induced in anesthetized mice by dropping a hollow aluminum cylindrical weight (300 g) through a vertical stainless steel tube onto a Lexon platform resting on the chest. The impact energy E (1.617 J) of the falling weight was calculated using the equation $\mathrm{E}=\mathrm{m} \times \mathrm{g} \times \mathrm{h}$ where $\mathrm{m}=$ mass of aluminium weight (in kilograms), $\mathrm{g}=$ gravitational acceleration $\left(9.8 \mathrm{~ms}^{-2}\right)$ and $\mathrm{h}=$ height of weight above the Lexon platform (in meters). Calculations assumed that all the potential energy of the weight was transferred to the animal, neglecting frictional dissipation. The platform was suspended on Teflon guides to minimize friction and facilitate energy transfer to the anesthetized animal. The shield was reproducibly placed entirely over the chest without intrusion onto the abdomen. Animals were sacrificed immediately after trauma, after 6, 12, 24 h, 3 and 7 days and samples for histologic examination were obtain afterwards.

\section{Protein analysis of MBD-4}

Blood samples obtained by heart puncture of mice were centrifuged for five minutes. The supernatant was removed and stored at $-20{ }^{\circ} \mathrm{C}$ until processed. Concentrations of MBD-4 in plasma samples were analysed by Luminex assay according to standard protocols using LiquiChip200 (Qiagen). A MBD-4 Elisa kit (ABIN415726, antibodies online $\mathrm{GmbH}$ ) was used for protein detection. Every experiment was accomplished three times.

\section{Immunhistology/Liver tissue of mice}

Six Liver tissue samples of mice were embedded in paraffin. Sections $(5 \mu \mathrm{m})$ were cut out of the central portion of the liver with a sliding microtome (HM 430; Microm International). They were placed onto Superfrost Plus microscope slides (Thermo Scientific) and left overnight at $60{ }^{\circ} \mathrm{C}$. Sections were routinely stained with hematoxylin and eosin (H\&E). Safranin O staining was carried out for 6 min, using a $0.1 \%$ aqueous solution at $\mathrm{pH}$ 3.0.

\section{Real-time PCR}

For real-time polymerase chain reaction (PCR), RNA was isolated from mice liver tissue with the RNeasyTotal RNA Kit (Qiagen, Hilden, Germany) according to the manufacturer's instructions. Total RNA (1,000 ng) was used for reverse transcription and subsequent Real-time PCR with gene-specific primers. Real-time PCR was performed as described by Varoga et al. [22]. The gene of interest was detected using TaqMan probes: Mm00731768_m1 (Applied Biosystems, Foster City, CA, USA).

\section{Statistical analysis}

Data is expressed as the mean $\pm \mathrm{SD}$ of tested samples. Statistical significance was evaluated using one-way ANOVA with Bonferroni correction. Statistical significance was assumed where probability values of less than 0.05 were obtained. Spearman's linear regression analysis was performed to evaluate correlation of protein plasma concentrations.

\section{Results}

HBD-2 concentration in plasma samples of multiple trauma patients

First we analysed plasma of multiple injured patients and as a control plasma of healthy donors for HBD-2 retrospectively. On the day of trauma protein levels increased 6 times compared to the healthy control group $(0.65 \mathrm{ng} / \mathrm{ml} \pm 0.31)$ to a maximum concentration of $4.2 \mathrm{ng} / \mathrm{ml} \pm 1.7$ (Fig. 1a). On day five HBD-2 expression decreased compared to day of trauma but was still significantly higher than the control group. Subsequent levels decreased, but did not reached levels of healthy donors on day 14 .

\section{MBD-4 concentration in plasma samples of mice after multiple trauma}

Host defence peptides in plasma of multiple traumatised mice were evaluated directly after trauma until day 7 . MBD-4 levels increased significantly to $15.18 \pm 2.2 \mathrm{ng} / \mathrm{ml}$ on day of trauma compared to control group $(3.79 \pm$ $0.5 \mathrm{ng} / \mathrm{ml}$; Fig. 1b). MBD-4 levels decreased afterwards, but did not reach the concentrations of control until day 7 .

HBD-2 concentration in samples of lysed liver tissue, skin and PMN

To evaluate possible sources of HBD-2 in human plasma we analysed liver and PMN, whether they contained comparable protein concentrations as skin, a wellknown producer of HBD-2 (Fig. 2). As expected skin samples contained the highest concentration of HBD-2 (7.12 ng/mg wet weight \pm 0.5 ). Liver tissue lysate showed less concentration of HBD-2 compared to skin (5.55 ng/ 

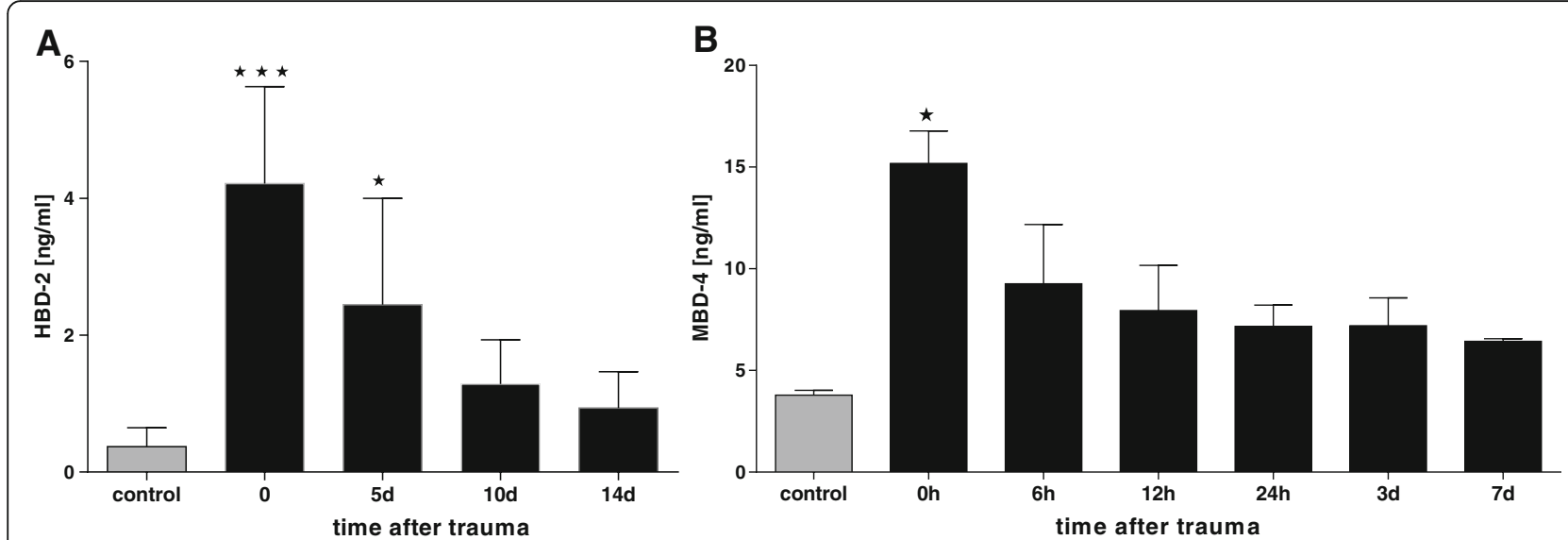

Fig. 1 Concentration of host defence peptides in plasma of humans and mice after multiple trauma. a ELISA analysis shows HBD-2 in plasma samples of multiple traumatized patients from day 0 , day 3, day 7 and day 14 after multiple trauma. Expression was compared to the expression of a healthy control group. $\mathbf{b}$ In trauma mouse model significant induction of MBD-4 was detected directly after hit. Analogue to human the highest levels were measured on day of trauma. ${ }^{* * *}=p<0.001 ;{ }^{*}=p<0.05$ versus controls; $\mathrm{d}=\mathrm{days} ; \mathrm{h}=\mathrm{hours}$

mg wet weight \pm 0.5 ), but higher concentration compared to PMN (0.3 ng/mg wet weight \pm 0.5$)$.

\section{Immunohistochemestry of host defence peptides in liver tissue of humans and multiple trauma mice} Immunohistochemistry was performed in liver specimens of non-trauma patients to confirm the detection of HBD-2 (Fig. 3a + b). Human liver samples showed strong positive staining for HBD-2. Mice liver of animals with multiple trauma revealed positive $\mathrm{MBD}-4$ staining, whereas control liver showed no reactivity (Fig. $3 c+d)$.

\section{Gene expression of MBD-4 in liver samples of multiple trauma mice}

Increase of MBD-4 in mice liver after multiple trauma was verified by real-time PCR. Analogue to plasma levels expressions raised after $6 \mathrm{~h}$ (4.3-fold of sham \pm 3.4$)$ and $12 \mathrm{~h}$ (2.9-fold of sham \pm 2.3 ) up to 5.0-fold of sham expression. The MDB-4 expression reached sham levels after $24 \mathrm{~h}$ (1.0-fold of sham \pm 0.5 ) (Fig. 4).

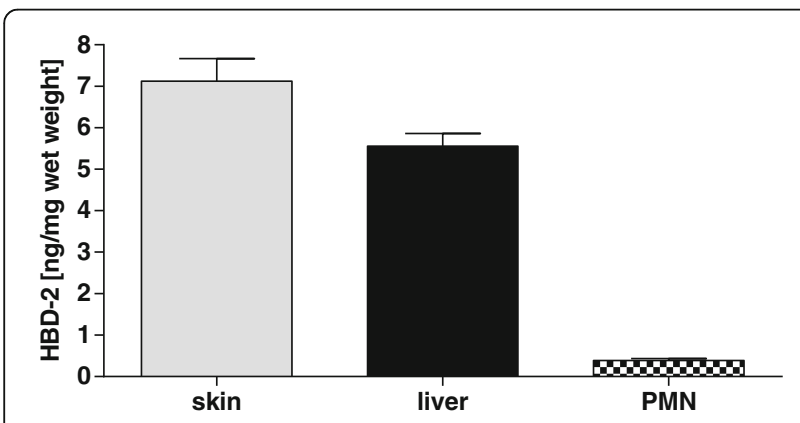

Fig. 2 Analysis of different sources for HBD-2 in human plasma. Samples of skin, liver and PMN of healthy donors were tested by Elisa analysis. Human liver samples contain similar concentrations of HBD- 2 compared to skin. Neutrophil granulocytes hold lowest levels
Induction of HBD-2 in immortalized hepatocytes

To evaluate induction of HBD-2 in immortalized hepatocytes (Hep G2), cells were stimulated with IL-6 (8.6 ng/ml \pm 0.1$)$, Staphylococcus aureus $(11.2 \mathrm{ng} / \mathrm{ml} \pm$ 1.1) and Staphylococcus aureus in combination with IL$6(11.5 \mathrm{ng} / \mathrm{ml} \pm 0.8)$. Lysates were tested by Elisa (Fig. 5). HBD-2 induction increased compared to control $(5.2 \mathrm{ng} / \mathrm{ml} \pm 1)$ but interestingly stimulation with SA and IL-6 did not cause a higher HBD-2 expression compared to stimulation with SA.

\section{Role of TLR2 in HBD2 induction in Hep G2 cells}

HBD-2 induction is regulated by toll-like receptors, especially TLR2. Hep G2 were incubated with TLR2 blocking antibody ( $\alpha$ TLR2), SA and SA together with $\alpha$ TLR2 (Fig. 6). After neutralisation with $\alpha$ TLR2 HBD-2 concentration was slightly decreased compared to control levels (7.3 ng/ml \pm 0.9$)$. The increase of HDP after treatment with SA + $\alpha$ TLR2 was significantly lower compared to stimulation with SA alone. Significant HBD-2 upregulation could be shown after stimulation with SA $(10.0 \mathrm{ng} / \mathrm{ml} \pm 1.3)$.

\section{Discussion}

Due to extended wounds and open fractures multiple injured patients are exposed to a multiplicity of invading gram-positive and -negative bacteria. Regarding this precarious premises one might believe that the overall sepsis rate is relatively low [2, 23]. In a previous study we were able to demonstrate that plasma of multiple injured patients provides an increased antimicrobial activity compared to healthy individuals [5]. In addition we detected HDP with its direct ability to invade microbes as possible effectors for the antimicrobial capacity. 


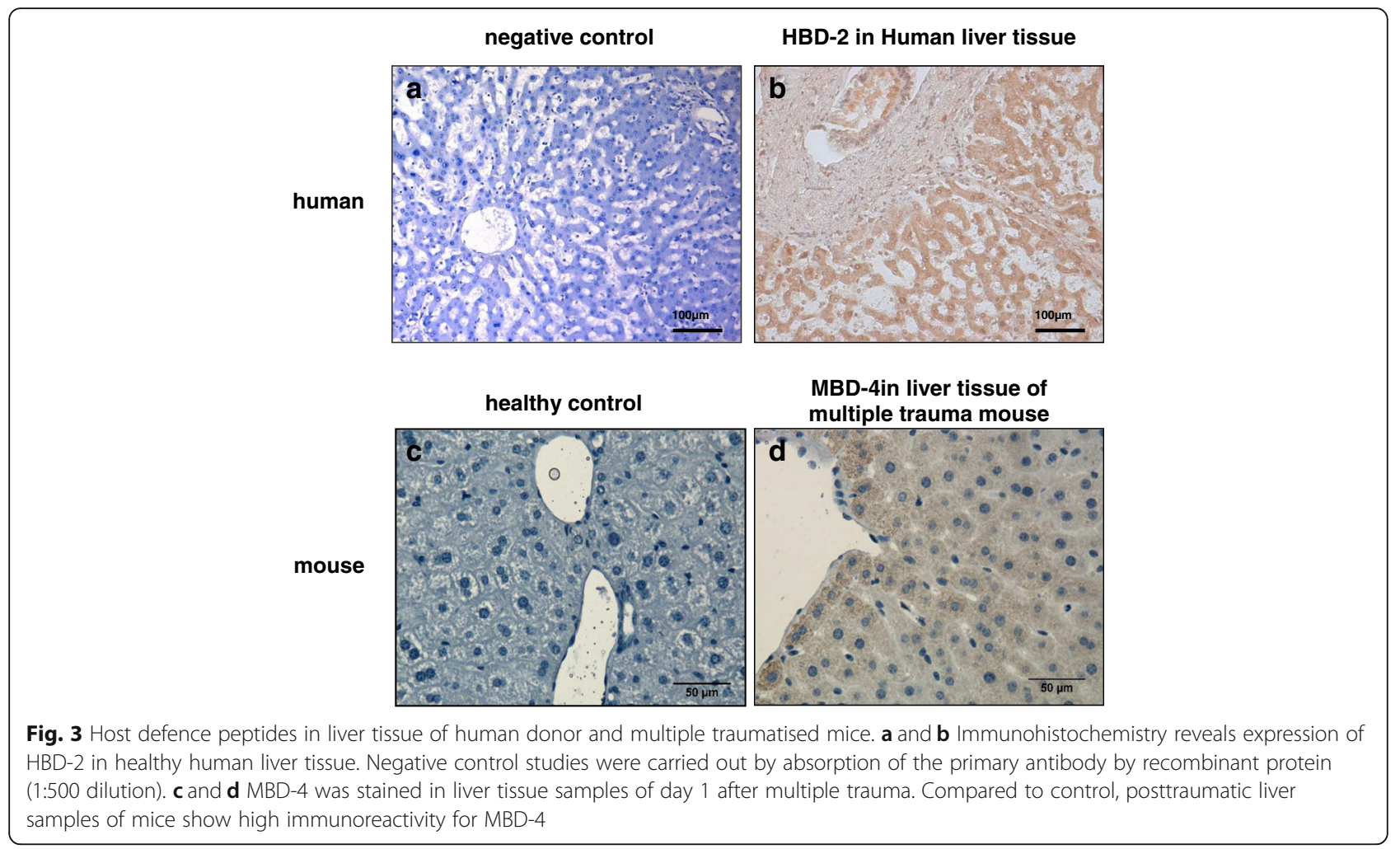

Nevertheless a possible source for the HDP and possible regulating pathways have not been investigated yet.

The liver is known as a major source of acute phase proteins, which are recognized as important components of the innate immune system $[16,24]$. In the current study we could show that liver tissue contains similar amounts of HBD-2 as skin tissue, which is recognized as a main producer for HBD [25]. Therefore we analysed the HBD-2 expression in

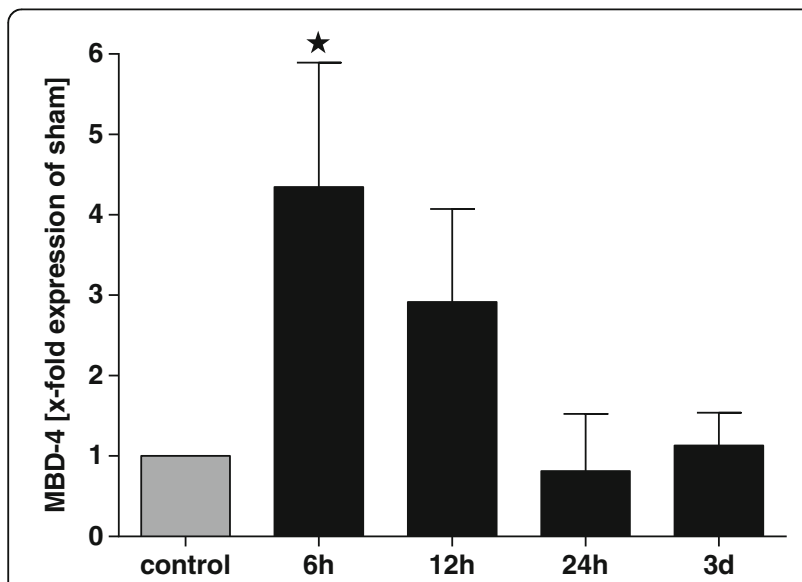

Fig. 4 Elevation of MBD-4 in liver cells of mice after multiple trauma. Induction of MBD-4 in liver of traumatised mice over a period of 3 days detected by real-time PCR. Significant elevation of MBD- 4 can be detected after $6 \mathrm{~h}$ after trauma compared to control group. ${ }^{*}=p<0.05$ liver tissue immunohistochemically and could detect hepatocytes as the main producer. Due to the fact that human hepatocytes of multiple injured patients is hardly available for research, we had to apply an established multiple trauma mouse model [26]. MBD4 constitutes an inducible orthologues of HBD-2 and holds strong antimicrobial activity as well [27].

In the present study we were able to show, that the time course of MBD-4 levels in plasma of trauma mice has a similar trend to the HBD-2 levels in plasma of multiple injured patients. Highest levels of MBD-4 were

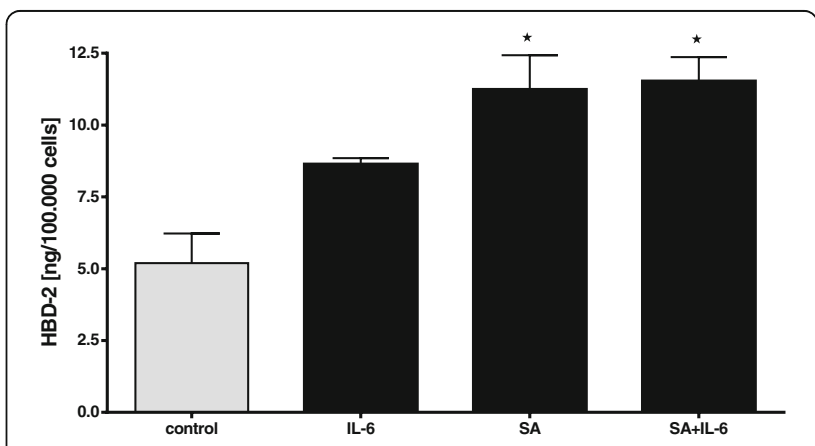

Fig. 5 In vitro stimulations of HBD-2 in Hep G2 cells. Human immortalized liver cell (Hep G2) were stimulated with bacteria and proinflammatory cytokines and concentrations of HBD-2 in lysates were analysed by ELISA. Significant up-regulation of HBD-2 after stimulation with SA and SA + IL-6 were detected in HepG2 cells. ${ }^{*}=p<0.05$ versus control 


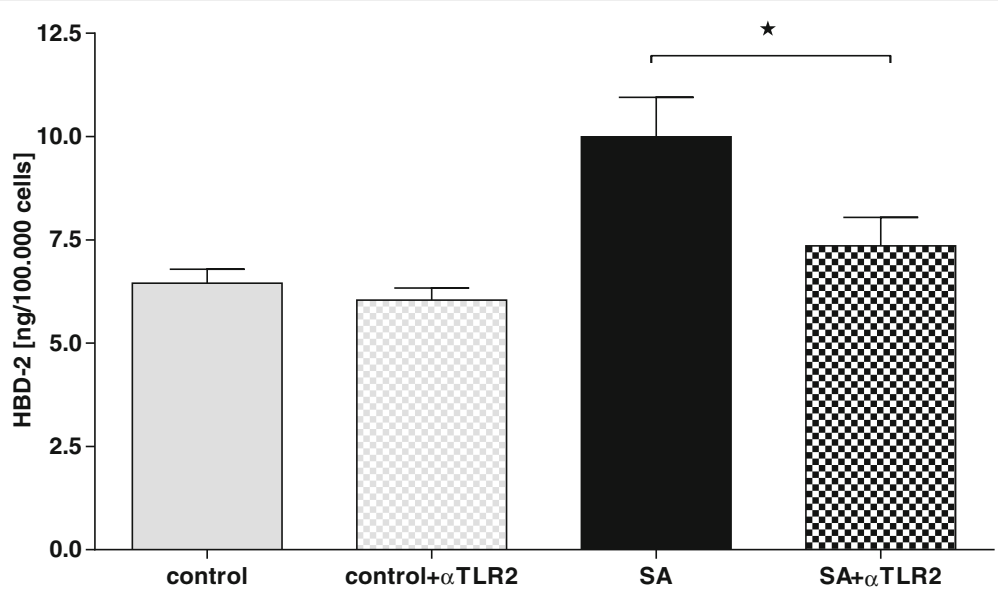

Fig. 6 Role of TLR2 in HBD-2 induction in Hep G2 cells. TLR2 was blocked with Antibodies (aTLR2) and stimulated with SA afterwards. The induction of HBD-2 in immortalized liver cell culture was measured by Elisa after stimulation. Compared to sample with blocked TLR2 a significant increase can be seen for HBD-2 after stimulation with SA. * $=p<0.05$ SA versus SA + aTLR2

detected immediately after trauma, decreased afterwards and even after 7 days plasma concentrations did not reach the concentration of the heathy mice.

In further investigations we demonstrated that MBD-4 expression is induced in liver tissue after multiple trauma. The plasma concentrations of MBD-4 correlated with their expression in liver. These findings were supported by our immunohistochemical staining of liver tissue from traumatised mice, in which we determined higher MBD-4 concentrations compared to liver of a healthy mice. It can be assumed that liver is one source for HDP in plasma after multiple injury.

Hypovolemic shock, hepatic ischemia and reperfusion injury as it occurs in multiple trauma patients stimulate the production of reactive oxygen species and the release of cytokines [28]. To get one step forward to comprehend the regulation of HBD-2 after multiple trauma we stimulated liver tissue with cytokines and gram-positive bacteria. As shown before bacteria seem to be a strong inducer for lysozyme in different tissues [29]. With regards to open fracture, wounds and deep tissue contusion, bacteria are a major cause for systemic infection after trauma. Our in vitro data revealed that SA induce HBD-2 in liver. Tissue damage seems to be another initiator of posttraumatic inflammatory reaction and besides the degree of tissue damage correlates with release of pro-inflammatory cytokines like IL-6 [30-32]. Due to the fact that IL- 6 plays a major role in posttraumatic inflammatory reaction [33], we tested the key player for its effect on HBD-2 expression in liver tissue. IL-6 shows non-significant induction of HBD-2 in liver tissue and hepatocytes, whereas SA seems to be the strongest inductor. HBD-2 induction by gram-positive bacteria has been reported in epithelial cells but not in hepatocytes [34, 35].
Relating to systemic inflammation and shock syndrome, liver constitutes a key figure in terms of the regulation of mediators (28) and regulate innate defence after severe injury (29).

To extend the comprehension of HBD-2 regulation in hepatocytes we identified one signalling pathway in hepatocytes. As shown before in epithelial cells TLR2 is involved in the regulation of HBD-2 [36, 37]. Furthermore TLR constitute the major mediators of inflammatory responses in liver and recognize microbial components as well as endogenous ligands from damaged or stressed cells $[38,39]$.

Toll-like receptors promote proinflammatory signalling such as the nuclear factor- $\mathrm{kB}$, c-Jun-N-terminal kinase (JNK), p38, and interferon pathways in the liver and regulate antiviral and antibacterial responses, hepatic injury, and wound healing [39]. In the present study we could demonstrate, that after blocking TLR2 with neutralizing antibodies, stimulation of hepatocytes with SA showed no effect. We assume that TLR 2 is not only involved in HBD-2 regulation in epithelial cells, but also in hepatocytes.

\section{Conclusion}

For the first time we provide evidence, that the liver is involved in the regulation of HBD-2 after multiple trauma. With the current study we increase the understanding of the complex immune reaction after severe injury. We are well aware of the fact that there are other sources for HBD-2 which can be recruited in case of trauma. Furthermore it can be assumed that there exists a multiplicity of other HDP and other features of this heterogenic group with respect to multiple trauma and critical care. Considering the complexity of this issue, the role of HDP in trauma will require further attention. 


\section{Acknowledgements}

We thank I. Geurink, G. Nessenius and K. Lange for their technical assistance.

\section{Funding}

This work was supported by the AO foundation 2010 and 2011, "Verein zur Förderung der Erforschung und Bekämpfung rheumatischer Erkrankungen Bad Bramstedt e.V" and by the SFB 617, A22 (D.V, R.M. and T.P.).

\section{Availability of data and material}

The datasets during and/or analysed during the current study available from the corresponding author on reasonable request.

\section{Authors' contributions}

SF carried out the surgical procedures and participated in its design and coordination MW carried out the surgical procedures and participated in its design and coordination. SL designed the study, participated in its coordination and helped to draft the manuscript. PB performed and interpreted PCR and ELISA of plasma and tissue samples. SF carried out the histologic staining and participated in its design and coordination. TP participated in the design of the study and performed the statistical analysis. MT performed ELISA of MBD-4 (Luminex). AB performed the statistical analysis. AS conceived of the study and participated in its design. DV designed the study, participated in its coordination and helped to draft the manuscript. TK drafted the manuscript, participated in its design and performed the statistical analysis. All authors read and approved the final manuscript.

\section{Competing interests}

The authors declare that they have no competing interests.

\section{Consent for publication}

Not applicable.

\section{Ethics approval and consent to participate}

The ethics approval was obtained prior to the study for trauma patient as well as for volunteer (control group) sample analysis from Ethics Committee of Christian-Albrechts-University, Kiel (AZ: D 415/08) and for animal studies from Ethics Committee of the Medizinische Hochschule Hannover (AZ: V 312-72241.121-9 (25-2/11)). Informed consent to participate in the study was obtained from all participants.

\section{Author details}

'Department of Trauma Surgery, University Medical Center of Schleswig-Holstein, Campus Kiel, Arnold-Heller-Strasse 3, 24105 Kiel, Germany. ${ }^{2}$ Department of Trauma Surgery, University of Aachen, Pauwelsstrasse 30, 52074 Aachen, Germany. ${ }^{3}$ Department of Cardiovascular Surgery, University Medical Center of Schleswig-Holstein, Campus Kiel, Arnold-Heller-Strasse 3, 24105 Kiel, Germany.

\section{Received: 11 July 2016 Accepted: 21 February 2017}

\section{Published online: 07 March 2017}

\section{References}

1. Lazarus HM, Fox J, Lloyd JF, Evans RS, Abouzelof R, Taylor C, Pombo DJ, Stevens MH, Mehta R, Burke JP. A six-year descriptive study of hospitalassociated infection in trauma patients: demographics, injury features, and infection patterns. Surg Infect (Larchmt). 2007;8(4):463-73.

2. Oberholzer A, Keel M, Zellweger R, Steckholzer U, Trentz O, Ertel W. Incidence of septic complications and multiple organ failure in severely injured patients is sex specific. J Trauma. 2000:48(5):932-7.

3. Flohe SB, Flohe S, Schade FU. Invited review: deterioration of the immune system after trauma: signals and cellular mechanisms. Innate Immun. 2008;14(6):333-44

4. Flohe S, Flohe SB, Schade FU, Waydhas C. Immune response of severely injured patients-influence of surgical intervention and therapeutic impact. Langenbecks Arch Surg. 2007;392(5):639-48

5. Lippross S, Klueter T, Steubesand N, Oestern S, Mentlein R, Hildebrandt F, Podschun R, Pufe T, Seekamp A, Varoga D. Multiple trauma induces serum production of host defence peptides. Injury. 2012;43(2):137-42.

6. Fehlbaum P, Rao M, Zasloff M, Anderson GM. An essential amino acid induces epithelial beta -defensin expression. Proc Natl Acad Sci U S A 2000;97(23):12723-8.
7. Thoma-Uszynski S, Stenger S, Takeuchi O, Ochoa MT, Engele M, Sieling PA, Barnes PF, Rollinghoff M, Bolcskei PL, Wagner M, et al. Induction of direct antimicrobial activity through mammalian toll-like receptors. Science. 2001; 291(5508):1544-7.

8. Zasloff M. Antimicrobial peptides of multicellular organisms. Nature. 2002; 415(6870):389-95.

9. Zhu S, Aumelas A, Gao B. Convergent evolution-guided design of antimicrobial peptides derived from influenza A virus hemagglutinin. Med Chem. 2011:54(4):1091-5.

10. Gallo RL, Ono M, Povsic T, Page C, Eriksson E, Klagsbrun M, Bernfield M. Syndecans, cell surface heparan sulfate proteoglycans, are induced by a proline-rich antimicrobial peptide from wounds. Proc Natl Acad Sci U S A. 1994:91(23):11035-9.

11. Huang HJ, Ross CR, Blecha F. Chemoattractant properties of PR-39, a neutrophil antibacterial peptide. J Leukoc Biol. 1997:61(5):624-9.

12. Li J, Post M, Volk R, Gao Y, Li M, Metais C, Sato K, Tsai J, Aird W, Rosenberg RD, et al. PR39, a peptide regulator of angiogenesis. Nat Med. 2000;6(1):49-55

13. Yang RB, Mark MR, Gray A, Huang A, Xie MH, Zhang M, Goddard A, Wood WI, Gurney AL, Godowski PJ. Toll-like receptor-2 mediates lipopolysaccharide-induced cellular signalling. Nature. 1998;395(6699):284-8

14. Keel M, Trentz O. Pathophysiology of polytrauma. Injury. 2005;36(6):691-709.

15. Moshage $\mathrm{H}$. Cytokines and the hepatic acute phase response. J Pathol. 1997;181(3):257-66.

16. Sander LE, Sackett SD, Dierssen U, Beraza N, Linke RP, Muller M, Blander JM, Tacke F, Trautwein C. Hepatic acute-phase proteins control innate immune responses during infection by promoting myeloid-derived suppressor cell function. J Exp Med. 2010;207(7):1453-64

17. Gebhard F, Pfetsch H, Steinbach G, Strecker W, Kinzl L, Bruckner UB. Is interleukin 6 an early marker of injury severity following major trauma in humans? Arch Surg. 2000;135(3):291-5.

18. Varoga D, Paulsen FP, Kohrs S, Grohmann S, Lippross S, Mentlein R, Tillmann $B N$, Goldring MB, Besch L, Pufe T. Expression and regulation of human betadefensin-2 in osteoarthritic cartilage. J Pathol. 2006:209(2):166-73.

19. Jia HP, Wowk Sa, Schutte Bc, Lee Sk, Vivado A, Tack Bf, Bevins Cl, McCray PB Jr. A novel murine beta -defensin expressed in tongue, esophagus, and trachea. 2010 (0021 -9258 (Print))

20. Lu SC, Huang HY. Comparison of sulfur amino acid utilization for GSH synthesis between HepG2 cells and cultured rat hepatocytes. Biochem Pharmacol. 1994:47(5):859-69.

21. Glaser R, Harder J, Lange H, Bartels J, Christophers E, Schroder JM. Antimicrobial psoriasin (S100A7) protects human skin from Escherichia coli infection. Nat Immunol. 2005:6(1):57-64.

22. Varoga D, Pufe T, Harder J, Schroder JM, Mentlein R, Meyer-Hoffert U, Goldring MB, Tillmann B, Hassenpflug J, Paulsen F. Human beta-defensin 3 mediates tissue remodeling processes in articular cartilage by increasing levels of metalloproteinases and reducing levels of their endogenous inhibitors. Arthritis Rheum. 2005;52(6):1736-45

23. Probst C, Zelle BA, Sittaro NA, Lohse R, Krettek C, Pape HC. Late death after multiple severe trauma: when does it occur and what are the causes? J Trauma. 2009:66(4):1212-7.

24. Medzhitov R. Recognition of microorganisms and activation of the immune response. Nature. 2007:449(7164):819-26.

25. Harder J, Dressel S, Wittersheim M, Cordes J, Meyer-Hoffert U, Mrowietz U, Folster-Holst R, Proksch E, Schroder JM, Schwarz T, et al. Enhanced expression and secretion of antimicrobial peptides in atopic dermatitis and after superficial skin injury. J Invest Dermatol. 2010;130(5):1355-64.

26. Neunaber C, Oestern S, Andruszkow H, Zeckey C, Mommsen P, Kutter D, Stofen M, Krettek C, Hildebrand F. Cytokine productive capacity of alveolar macrophages and Kupffer cells after femoral fracture and blunt chest trauma in a murine trauma model. (1879-0542 (Electronic)).

27. Rohrl J, Yang D, Oppenheim JJ, Hehlgans T. Specific binding and chemotactic activity of mBD4 and its functional orthologue hBD2 to CCR6expressing cells. 2010 (1083-351X (Electronic)).

28. Klune JR, Tsung A. Molecular biology of liver ischemia/reperfusion injury: established mechanisms and recent advancements. Surg Clin North Am. 2010;90(4):665-77

29. Liu AY, Destoumieux D, Wong AV, Park CH, Valore EV, Liu L, Ganz T. Human beta-defensin-2 production in keratinocytes is regulated by interleukin-1, bacteria, and the state of differentiation. J Invest Dermatol. 2002;118(2):275-81 
30. Hauser CJ, Zhou X, Joshi P, Cuchens MA, Kregor P, Devidas M, Kennedy RJ Poole GV, Hughes JL. The immune microenvironment of human fracture/ soft-tissue hematomas and its relationship to systemic immunity. J Trauma. 1997:42(5):895-903. discussion 903-894.

31. Rose S, Marzi I. [Pathophysiology of polytrauma]. Zentralbl Chir. 1996; 121(11):896-913.

32. Strecker W, Gebhard F, Rager J, Bruckner UB, Steinbach G, Kinzl L. Early biochemical characterization of soft-tissue trauma and fracture trauma. J Trauma. 1999:47(2):358-64

33. Toth B, Yokoyama Y, Schwacha MG, George RL, Rue 3rd LW, Bland Kl, Chaudry $\mathrm{IH}$. Insights into the role of interleukin- 6 in the induction of hepatic injury after trauma-hemorrhagic shock. J Appl Physiol. 2004;97(6):2184-9.

34. Kumar A, Zhang J, Yu F-SX. Toll-like receptor 2-mediated expression of $\beta$ defensin-2 in human corneal epithelial cells. Microbes Infect. 2006;8(2):380-9.

35. Vora P, Youdim A, Thomas LS, Fukata M, Tesfay SY, Lukasek K, Michelsen KS, Wada A, Hirayama T, Arditi M, et al. Beta-defensin-2 expression is regulated by TLR signaling in intestinal epithelial cells. J Immunol. 2004;173(9):5398-405.

36. Ji S, Shin JE, Kim YS, Oh JE, Min BM, Choi Y. Toll-like receptor 2 and NALP2 mediate induction of human beta-defensins by fusobacterium nucleatum in gingival epithelial cells. Infect Immun. 2009;77(3):1044-52.

37. Varoga D, Klostermeier E, Paulsen F, Wruck C, Lippross S, Brandenburg LO, Tohidnezhad M, Seekamp A, Tillmann B, Pufe T. The antimicrobial peptide HBD-2 and the Toll-like receptors- 2 and -4 are induced in synovial membranes in case of septic arthritis. Virchows Arch. 2009;454(6):685-94.

38. Ishii K, Akira S. Toll-like receptors and sepsis. Curr Infect Dis Rep. 2004;6(5):361-6.

39. Schwabe RF, Seki E, Brenner DA. Toll-like receptor signaling in the liver. Gastroenterology. 2006;130(6):1886-900.

\section{Submit your next manuscript to BioMed Central and we will help you at every step:}

- We accept pre-submission inquiries

- Our selector tool helps you to find the most relevant journal

- We provide round the clock customer support

- Convenient online submission

- Thorough peer review

- Inclusion in PubMed and all major indexing services

- Maximum visibility for your research

Submit your manuscript at www.biomedcentral.com/submit 